\title{
Pengembangan Mobile Learning Sebagai Sumber Belajar Fisika Pada Materi Gerak Lurus Untuk Siswa Kelas X
}

\author{
Sesarius Yohanes Goda Toda*, Aloisius Harso, Richardo Barry Astro
}

\author{
Physics Education Department, Universitas Flores, J1. Sam Ratulangi No. X, Ende, \\ Nusa Tenggara Timur, Indonesia \\ Corresponding email: sesariusjo@gmail.com
}

\author{
Sejarah Artikel \\ Dikirim: November 2021 \\ Diterima: Desember 2021 \\ Dipublikasi: Desember \\ 2021
}

\section{Kata Kunci}

Mobile Learning;

Sumber Belajar Fisika;

Gerak Lurus

\begin{abstract}
Abstrak
Penelitian ini bertujuan untuk menghasilkan produk berupa mobile learning yang layak digunakan sebagai sumber belajar fisika siswa kelas $\mathrm{X}$ pada materi gerak lurus. Jenis penelitian ini adalah penelitian pengembangan (Research and Development) dan menggunakan desain pengembangan ADDIE dengan menggunakan kuesioner berupa angket untuk mengukur kelayakan produk yang dihasilkan. Subjek dalam penelitian berjumlah 18 orang yang meliputi 1 ahli media, 1 ahli materi, 2 guru fisika, 4 teman sejawat mahasiswa program studi pendidikan fisika (peer reviewer) dan 10 siswa kelas 10 SMA pengguna telepon genggam android. Analisis data yang digunakan dalam penelitian dan pengembangan ini menggunakan analisis data deskriptif kualitatif dan kuantitatif. Data kualitatif dan kuantitatif dikumpulkan menggunakan instrumen berupa angket yang diperoleh digunakan sebagai dasar dalam perbaikan mobile learning. Hasil penelitian menunjukan bahwa produk berupa mobile learning layak digunakan sebagai sumber belajar fisika siswa kelas X pada materi gerak lurus berdasarkan penilaian ahli media sebesar $80 \%$, penilaian ahli materi sebesar $70 \%$, dan penilaian guru fisika sebesar $82,54 \%$ dengan kriteria layak/baik. Hasil uji coba terbatas menunjukan mobile learning yang dikembangkan sangat layak/sangat baik dengan rata-rata penilaian oleh peer reviewer sebesar $85,66 \%$ dan rata-rata penilaian oleh siswa sebesar $93,33 \%$.
\end{abstract}

\section{Development of Mobile Learning as a Source of Physics Learning in Straight Motion Materials for Class $X$ Students}

\section{Article History}

Received: November 2021

Accepted: December 2021

Published: December 2021

Key Words

Mobile Learning;

Physics Learning

Resources;

Straight Motion

How to cite this article?
Abstract

This study aims to produce a product in the form of mobile learning that is suitable for use as a source of learning physics for class $X$ students on straight motion material generated. The subjects in the study were 18 people which included 1 media expert, 1 material expert, 2 physics teachers, 4 colleagues from physics education study program students (peer reviewers) and 10 10th grade high school students using android mobile phones. Analysis of the data used in this research and development uses descriptive qualitative and quantitative data analysis. Qualitative and quantitative data were collected using an instrument in the form of a questionnaire obtained to be used as a basis for improving mobile learning. The results showed that the product in the form of mobile learning was appropriate to be used as a source of learning physics for class $X$ students in straight motion material based on the assessment of media experts by $80 \%$, expert judgment the material is 70\%, and the physics teacher's assessment is $82.54 \%$ with decent/good criteria. The results of the limited trial show that the developed mobile learning is very feasible/very good with an average assessment by peer reviewers of $85.66 \%$ and an average assessment by students of $93.33 \%$.

Toda, S., Harso, A., \& Astro, R. (2021). Pengembangan Mobile Learning Sebagai Sumber Belajar Fisika Pada Materi Gerak Lurus Untuk Siswa Kelas X. Lensa: Jurnal Kependidikan Fisika, 9(2), 124-141. doi:https://doi.org/10.33394/j-1kf.v9i2.4387 


\section{PENDAHULUAN}

Proses pembelajaran di era globalisasi saat ini menuntut guru selaku tenaga pendidik yang menyelenggarakan proses belajar mengajar di dalam kelas harus memiliki kompetensi dalam menggunakan Teknologi Informasi dan Komunikasi (TIK), terutama dalam penggunaan komputer dan internet. Dalam Peraturan Pemerintah Republik Indonesia No 74 Tahun 2008 Pasal 3 disebutkan bahwa 4 kompetensi yang harus dimiliki oleh seorang guru yang meliputi: kompetensi pedagogik, kompetensi kepribadian, kompetensi profesional, dan kompetensi sosial (Sugiyono, 2018). Kompetensi pedagogik merupakan kemampuan atau keterampilan guru dalam beberapa aspek salah satunya keterampilan pemanfaatan teknologi pembelajaran.

Teknologi sangat berpengaruh pada bidang pendidikan kemajuan bidang teknologi yang berpengaruh dalam dunia pendidikan misalnya internet dan android yang dapat dimanfaatkan sebagai sumber belajar selain dari buku (Sefriani \& Sepriana, 2020). Bahkan saat ini penggunaan android sudah menjadi basis media pembelajaran yang merupakan salah satu gaya belajar di Abad ke 21 (Calimag dkk., 2014). Berdasarkan hasil observasi selama 3 bulan di SMAN 1 GOLEWA hampir sebagian besar siswa telah memiliki telepon genggamberbasis android. Akan tetapi belum dimanfaatkan secara baik sebagai sumber belajar. Siswa mengeluhkan bahwa banyaknya bacaan di internet yang ditawarkan sebagai sumber belajar membuat siswa bingung untuk menentukan mana yang sesuai dengan kompetensi dan indikatorindikator yang telah ditetapkan.

Covid-19 yang sedang melanda di seluruh negara termasuk Indonesia sejak akhir tahun 2019 menyebabkan banyaknya korban meninggal akibat terinfeksi virus ini. Penanggulangan penyebaran virus Covid-19 coba diatasi dengan memberlakukan kebijakan new normal (kenormalan baru) dan Pembatasan Sosial Berskala Besar (PSBB). Dampak bagi sektor pendidikan di Indonesia yakni kebijakan penghapusan Ujian Nasional (UN) dan penutupan sementara sekolah (Kemendikbud, 2020). Belajar dari rumah pada saat new normal menyebabkan guru dan siswa terlibat dalam interaksi synchronous dan asynchronous (Oye dkk., 2012). Pemberlakuan kebijakan belajar di rumah mengharuskan guru agar bisa menyajikan materi dengan lebih kreatif, variatif, dan komunikatif.

Perkembangan teknologi pada saat ini sangat terasa, hal ini ditunjukandengan meningkatkanya penggunaan internet yang sangat signifikan yakni lebih dari $25 \%$ terutama selama masa darurat kesehatan di Indonesia (CNN Indonesia, 2020). Perkembangan teknologi ini dapat dimanfaatkan untuk mendukung kegiatan belajar di rumah secara daring.

Pembelajaran daring dapat diartikan sebagai suatu kegiatan belajar mengajar yang memanfaatkan jaringan atau koneksi internet supaya terjalin komunikasi antara guru dan muridnya tanpa melibatkan kontak fisik (Baskara dkk., 2020). Akan tetapi penggunaan aplikasi belajar seperti icando, google for education, zoom, quipper video, ruangguru, terdapat beberapa kendala dalam proses berlangsungnyakegiatan pembelajaran secara daring. Infrastruktur merupakan kendala terberat dalam kegiatan belajar mengajar secara daring yakni: penggunaan aplikasi pembelajaran virtual bisa dilaksanakan dengan baik harus memiliki konektivitas internet yang lancar. Permasalahannya beberapa daerah masih mengalami susah sinyal dan kuota internet yang tidak mencukupi serta sumber belajar yang masih kurang layak. Selain itu terkendalanya pembelajaran secara daring diakibatkan karena guru yang belum siap dengan pembelajaran secara daring dan penggunaan aplikasi pembelajaran virtual yang berbayar. 
Mobile learning adalah pemanfaatan perkembangantelepon genggamdan teknologi seluler dalam dunia pendidikan sebagai sumber belajar bagi siswa. Pengembangan mobile learning disajikan dalam bentuk gambar, teks, audio, dan video serta animasi (Yuniati, 2012). Format yang digunakan yaitu multimedia sehingga menjadi sumber belajar yang menarik dan mudah dipahami. Potensi dan prospek pengembangan mobile learning untuk kedepanya sangat terbuka lebar dikarenakan kecenderungan masyarakat yang semakin dinamis dan mobile serta tuntutan kebutuhan pendidikan yang beragam dan berkualitas (Astra, 2012). Konsep pembelajaran tersebut diharapkan bisa mendorong terciptanya suasana pembelajaran yang inovatif dan efektif sehingga dapat memotivasi semangat belajar siswa dan guru. Dengan adanya pandemi covid-19 ini mempercepat pengembangan mobile learning yang digunakan sebagai sumber belajar mandiri.

Beberapa hasil penelitian terdahulu seperti Wahyono, Kadek, dan Gagese (2018) menemukan bahwa produk hasil pengembangan mobile learning dinyatakan layak digunakan sebagai sumber belajar berdasarkan berdasarkan penilaian ahli, guru fisika, dan peer reviewer dengan kategori baik. Mobile Learning mampu meningkatkan motivasi belajar dan penguasaan materi Listrik Dinamis pada siswa kelas IX dengan kategori sedang berdasarkan nilai gain yang diperoleh sebesar 0,35. Senada dengan hasil penelitian tersebut Ertikanto, Sesunam, dan Purnama (2017) menemukan bahwa media pembelajaran mobile learning yang dikembangkan efektif untuk digunakan dan memiliki kemenarikan baik berdasarkan nilai gain ternormalisasi dengan skor 3,25; kualitas kemudahan sangat baik dengan skor 3,28; kualitas kebermanfaatan sangat baik dengan skor 3,32. Berdasarkan penilaian ahli mobile learning berbasis android yang dikembangkan juga layak digunakan sebagai media pembelajaran dan alternatif sumber belajar bagi siswa. Penelitian dan pengembangan yang akan peneliti lakukan memiliki kesamaan dengan penelitian di atas yaitu melakukan pengembangan mobile learning berbasis android sebagai sumber belajar. Penelitian dan pengembangan ini menggunakan kode program web 2 APK Builder Pro sedangkan penelitian dan pengembangan yang dilakukan oleh Wahyono, Kadek, dan Gagese (2018) menggunakan kode program javascript. Perbedaan penelitian dan pengembangan ini adalah pada materi pelajaran penelitian ini berfokus pada materi Gerak Lurus sedangkan penelitian terdahulu mengambil materi Listrik Dinamis dan Hukum Newton.

Berdasarkan potensi dan permasalahan yang telah diuraikan tersebut maka penelitian ini bertujuan untuk mengembangkan mobile learning sebagai sumber belajar berbasis android yang menyajikan pembelajaran fisika pada materi gerak lurus kelas $\mathrm{X}$. Produk yang dihasilkan berupa sebuah aplikasi android dan menjadi sebuah solusi dikarenakan aplikasi yang dibuat dengan terstruktur ini dapat digunakan oleh semua pengajar mata pelajaran fisika khususnya pada materi gerak lurus kelas X SMA. Selain itu, keunggulan mobile learning dalam penelitian ini adalah kemudahan dalam akses materi ajar pada saat pembelajaran karena tidak membutuhkan kuota dan sinyal internet.

\section{METODE}

Jenis penelitian yang digunakan dalam penelitian ini ialah penelitian pengembangan (Research and Development). Penelitian pengembangan merupakan proses yang dilakukan untuk mengembangkan suatu produk baru ataupun menyempurnakan sebuah produk yang sudah ada dan dapat dipertanggung jawabkan. Tujuan dari penelitian ini ialah untuk melakukan pengembangan mobile learning sebagai sumber belajar bagi siswa kelas X. Penelitian ini menggunakan desain 
pengembangan ADDIE yang meliputi lima tahapan, yakni: Analysis, Design, Development, Implementation, dan Evaluation seperti disajikan pada Gambar 1.

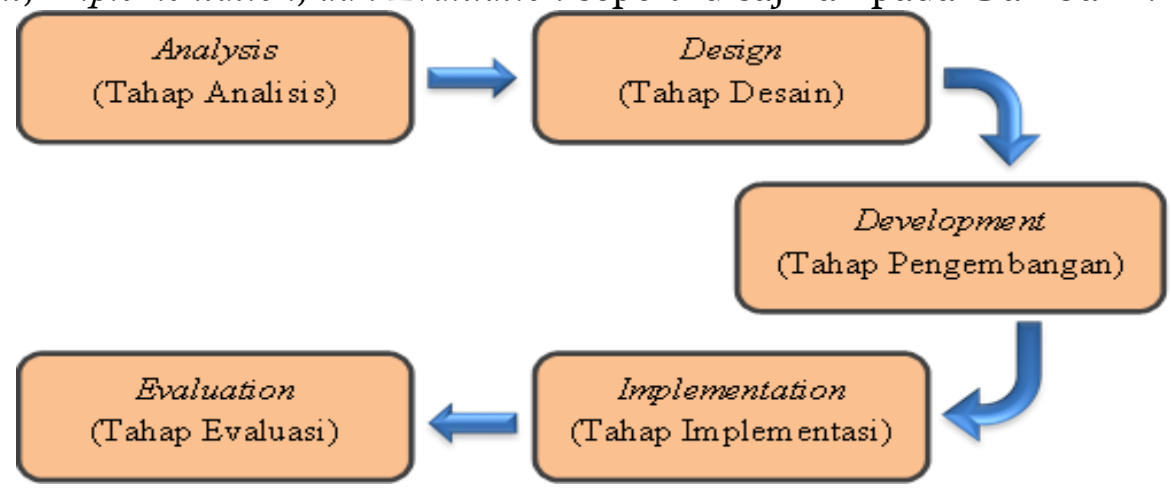

\section{Tahap Analysis}

Gambar 1. Model ADDIE (Pribadi, 2014)

Tahap analisis bertujuan untuk mengkaji kurikulum serta materi fisika kelas X SMA yang sesuai dengan standar isi sehingga dapat disampaikan melalui mobile learning. Proses analisis diawali dengan memilih materi pelajaran fisika yaitu materi gerak lurus kelas X SMA yang sesuai dengan kurikulum 2013 revisi. Tahap analisis juga dilakukan untuk mengkaji lebih lanjut mengenai Kompetensi Dasar (KD), indikator, dan tujuan pembelajaran yang akan dicapai pada materi gerak lurus.

\section{Tahap Design}

Pada tahap kedua produk dirancang atau didesain berdasarkaan hasil analisis. Produk yang dihasilkan ialah sumber belajar berupa mobile learning pada materi gerak lurus. Tahap desain dilakukan dengan pembuatan desain (storyboard) yang merupakan gambaran produk secara keseluruhan befungsi sebagai panduan.

Tahap Development

\section{Implementasi kode program}

Tahap ini hasil desain aplikasi dibuat dalam format microsoft power point yang sudah di konversi ke format HTML 5 dengan menggunakan Ispring Suite. Selanjutnya konversiHTML 5 ke aplikasi dengan meggunakan website 2 APK Builder Pro sehingga terbentuk sebuah produk aplikasi.

\section{Pengujian aplikasi}

Pada tahap ini bertujuan agar mendapatkan saran dan masukan dari dosen pembimbing sehingga mobile learning yang dikembangkan menjadi lebih baik sebelum diberikan kepada 1 ahli media dan 1 ahli materi selaku validator. Validator dipilih sebagai ahli media merupakan orang yang memahami secara mendalam mengenai sistem informatika dan ahli materi merupakan orang yang memahami secara mendalam sesuai dengan materi pembelajaran yang difokuskan.

\section{Tahap Implementation}

Tahap implementasi ini melibatkan 16 partisipan, diantaranya 10 siswa kelas $\mathrm{X}$ SMA pengguna telepon genggam android, 2 guru fisika, dan 4 peer reviewer yaitu teman sejawat program studi pendidikan fisika. Tujuannya untuk melihat kesalahan-kesalahan kecil yang luput dari pengamatan ahli media dan ahli materi.

\section{Tahap Evaluation}

Tahap evaluasi merupakan tahap akhir dari pengembangan mobile learningyang dilakukan. Peneliti melakukan revisi tahap akhir pada mobile learning berdasarkan saran dan masukan yang diberikan oleh siswa, guru fisika, dan peer reviewer. Revisi akhir ini 
bertujuan agar mobile learning yang dikembangkan benar-benar sesuai dan layak digunakan sebagai sumber belajar.

Teknik pengumpulan data berupa angket dengan raiting scale yang dibagikan kepada seluruh sebjek penelitian. Analisis data yang digunakan dalam penelitian dan pengembangan ini menggunakan analisis data deskriptif kualitatif dan kuantitatif. Data kualitatif dan kuantitatif yang diperoleh digunakan sebagai dasar dalam perbaikan mobile learning.

Analisis data kelayakan produk dikonversikan dalam 5 kriteria yaitu Sangat Layak, Layak, Cukup Layak, Kurang Layak, dan Tidak Layak. Produk mobile learning yang telah dikembangkan dapat dinyatakan layak untuk digunakan sebagai sumber belajar fisika kelas X pada materi gerak lurus apabila memperoleh persentase skor minimal $68 \%$ 83,9\% dengan kriteria "Layak". Jika hasil penilaian belum memenuhi kriteria tersebut, maka produk dinyatakan belum layak untuk digunakan sebagai sumber belajar.

Tabel 1. Aturan pemberian skor untuk ahli materi, ahli media, dan guru (Riduwan, 2013)

\begin{tabular}{ll}
\hline Keterangan & Skor \\
\hline SB (Sangat Baik) & 5 \\
B (Baik) & 4 \\
C (Cukup) & 3 \\
K (Kurang) & 2 \\
SK (Sangat Kurang) & 1 \\
\hline
\end{tabular}

Tabel 2. Range persentase dan kriteria kualitas produk (Riduwan, 2013)

\begin{tabular}{ll}
\hline Skor & Kriteria \\
\hline $84 \%-100 \%$ & Sangat Layak/Sangat Baik \\
$68 \%-83,9 \%$ & Layak/Baik \\
$52 \%-67,9 \%$ & Cukup Layak/Cukup Baik \\
$36 \%-51,9 \%$ & Kurang Layak/Kurang Baik \\
$\leq 35,9 \%$ & Tidak Layak/Tidak Baik \\
\hline
\end{tabular}

\section{HASIL DAN PEMBAHASAN}

Penelitian ini menggunakan pengembangan ADDIE yang meliputi lima tahapan, yakni: Analysis, Design, Development, Implementation, dan Evaluation. Mobile learning yang sudah dikembangkan divalidasi oleh ahli media dan ahli materi sebelum dilanjutkan ketahapan implementation. Pada tahapan implementation dilakukan Uji coba terbatas yang melibatkan 16 orang, diantaranya 2 orang guru fisika yaitu guru fisika SMAN 1 Ende dan guru fisika SMAK St. Petrus Ende; 10 siswa SMAN 1 Ende dan 4 orang peer reviewer yang merupakan teman seangkatan program studi pendidikan fisika.

\section{Pengembangan}

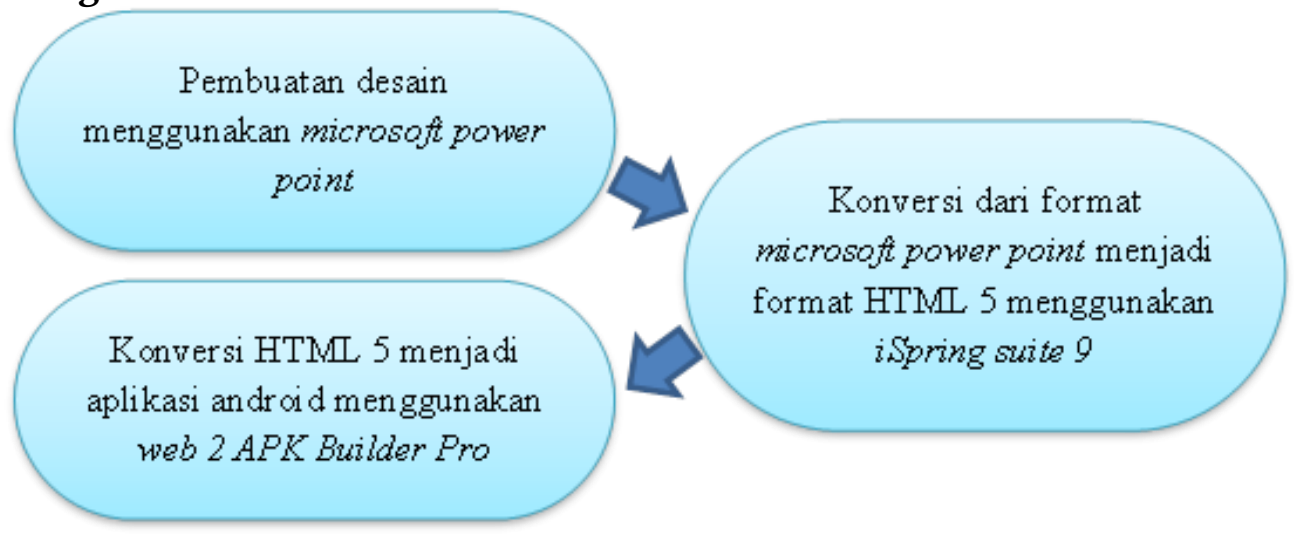

Gambar 2. Tahapan Pengembangan Mobile Learning 
Desain dari produk dibuat dengan menggunakan microsoft power point 2010 yang ada di komputer. Langkah-langkah pembuatan desain disajikan sebagai berikut.

1. Buku aplikasi microsoft power point 2010 , kemudian atur ukuran slide menjadi 16 X 9 pada menu design>page setup.

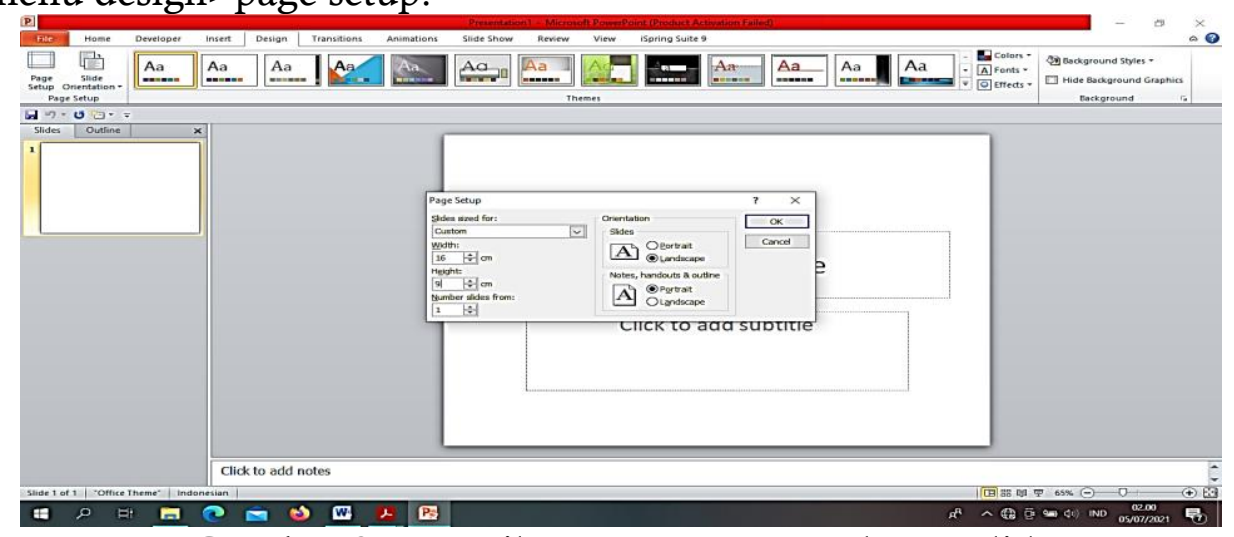

Gambar 3. Tampilan saat mengatur ukuran slide

2. Masukan latar belakang dengan cara pilih menu design $>$ background styles $>$ format background>picture or texture fill kemudian pilih gambar untuk dijadikan latar belakang lalu klik apply to all.

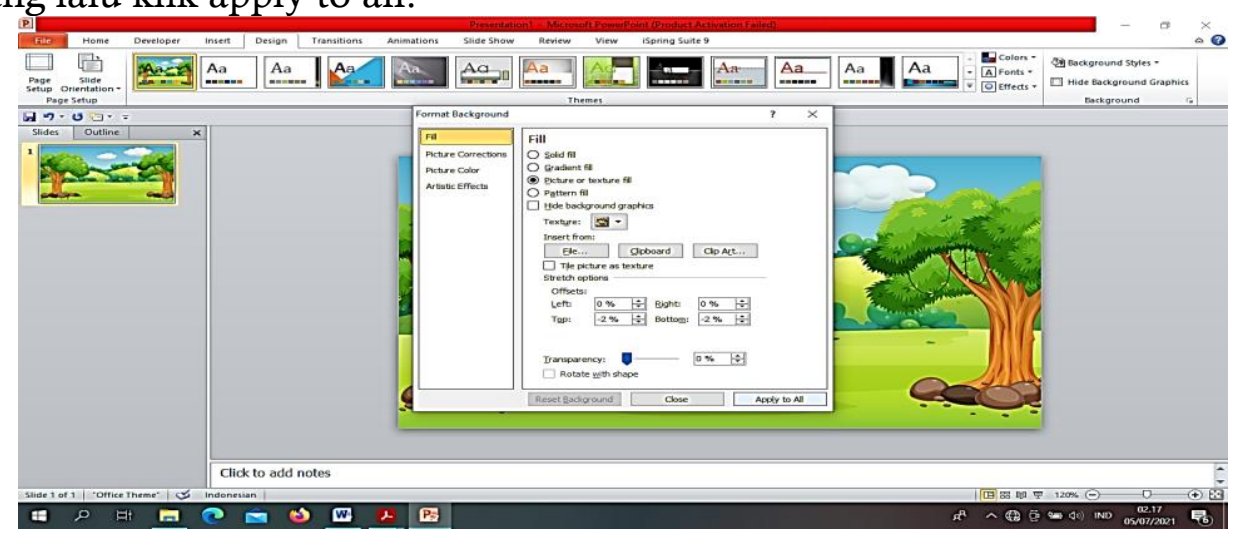

\section{Gambar 4. Tampilan saat memasukan latar belakang}

3. Masukan judul materi pembelajaran dan ikon yang nantinya saat produk sudah jadi item tersebut dapat diklik sebagai tanda mulai, caranya klik menu insert>picture kemudian pilih ikon dan klik insert.

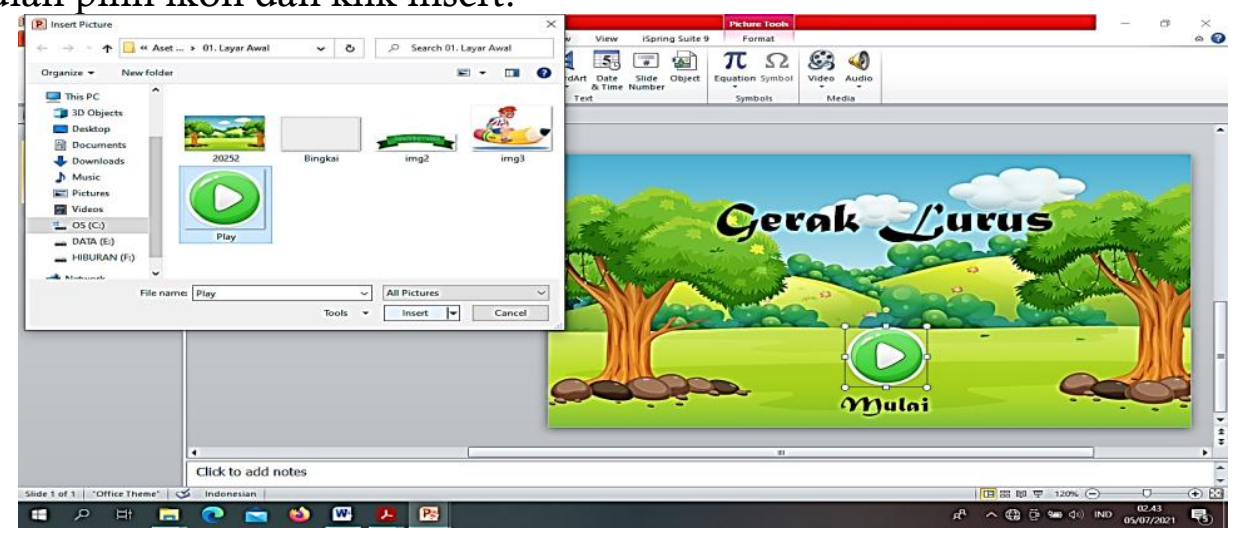

Gambar 5. Tampilan saat memasukan judul dan ikon tanda mulai

4. Membuat slide baru untuk dijadikan menu home dengan cara klik new slide kemudian masukan ikon kompetensi, materi, dan evaluasi yang nantinya item tersebut dapat dibuka. Atur ukuran ikonnya pada menu format>sesuaikan height dan width. 


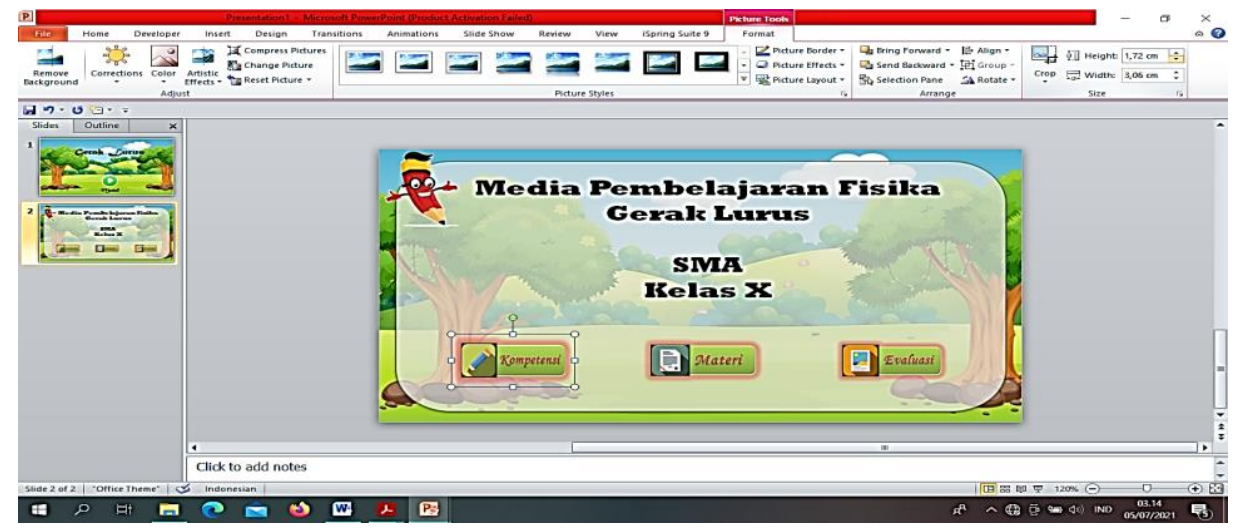

Gambar 6. Tampilan desain menu home

5. Klik menu home>new slide untuk memasukan $\mathrm{KD}, \mathrm{KI}$, indikator, tujuan pembelajaran, materi, video contoh soal dan evaluasi. Kemudian masukan ikon untuk dijadikan item menu home, kembali ke halaman sebelumnya dan menuju ke halaman berikutnya.

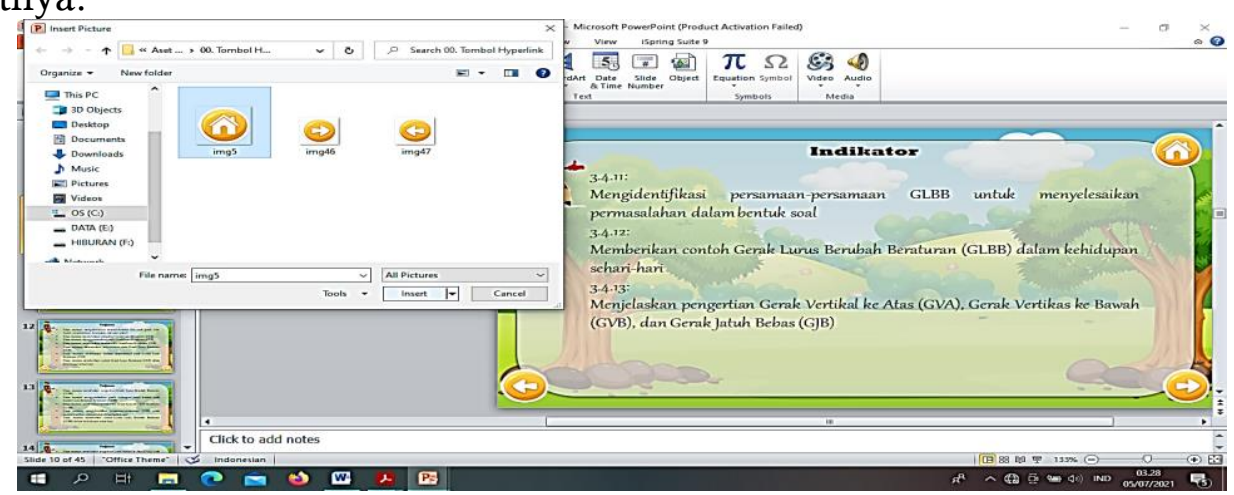

Gambar 7. Tampilan saat memasukan ikon untuk dijadikan item

6. Membuat animasi untuk memberikan gambaran mengenai jarak dan perpindahan dengan cara pilih new slide>insert $>$ shapes pilih rectangle untuk membuat lintasan mobil.

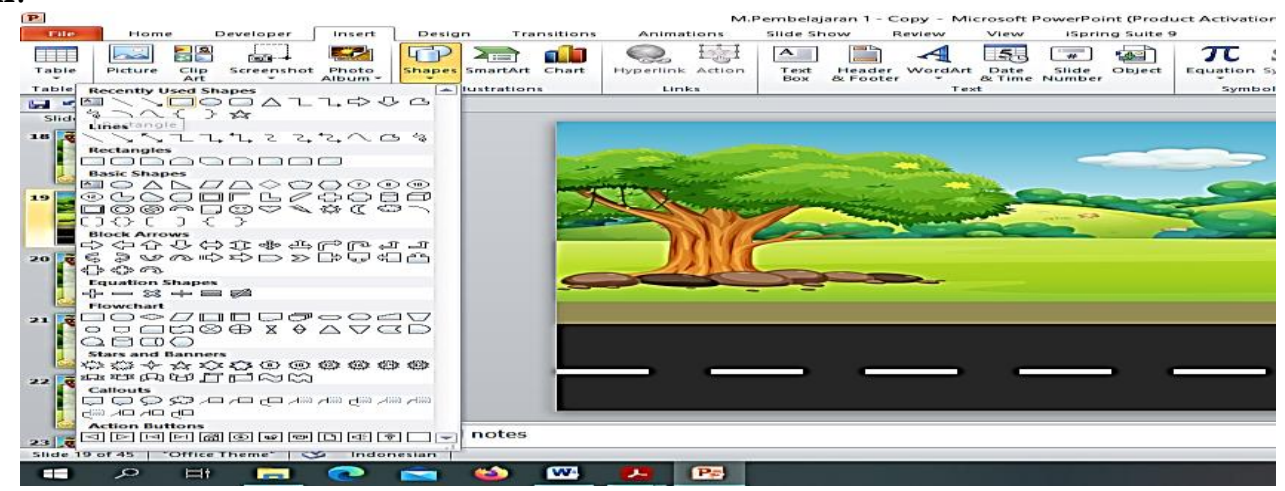

\section{Gambar 8. Tampilan saat membuat lintasan mobil}

7. Masukan gambar mobil lalu klik menu animations $>$ motion paths $>$ lines kemudian tarik ujung garis untuk mengatur panjang lintasan mobil. 


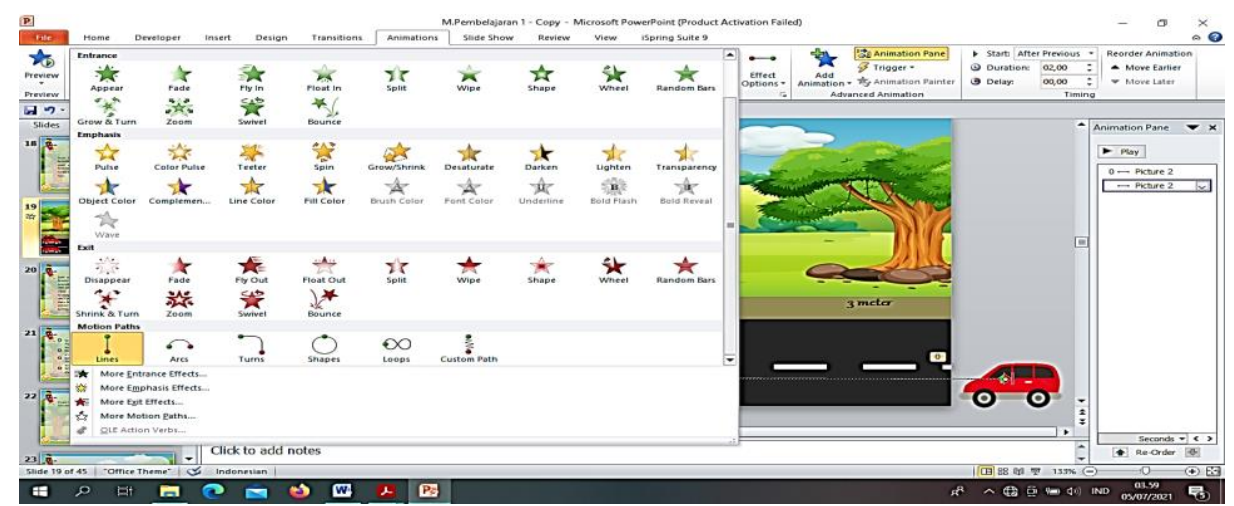

Gambar 9. Tampilan saat membuat gambar mobil bisa bergerak menjadi sebuah animasi

8. Membuat evaluasi dengan cara klik menu iSpring $>$ quis $>$ graded quis.

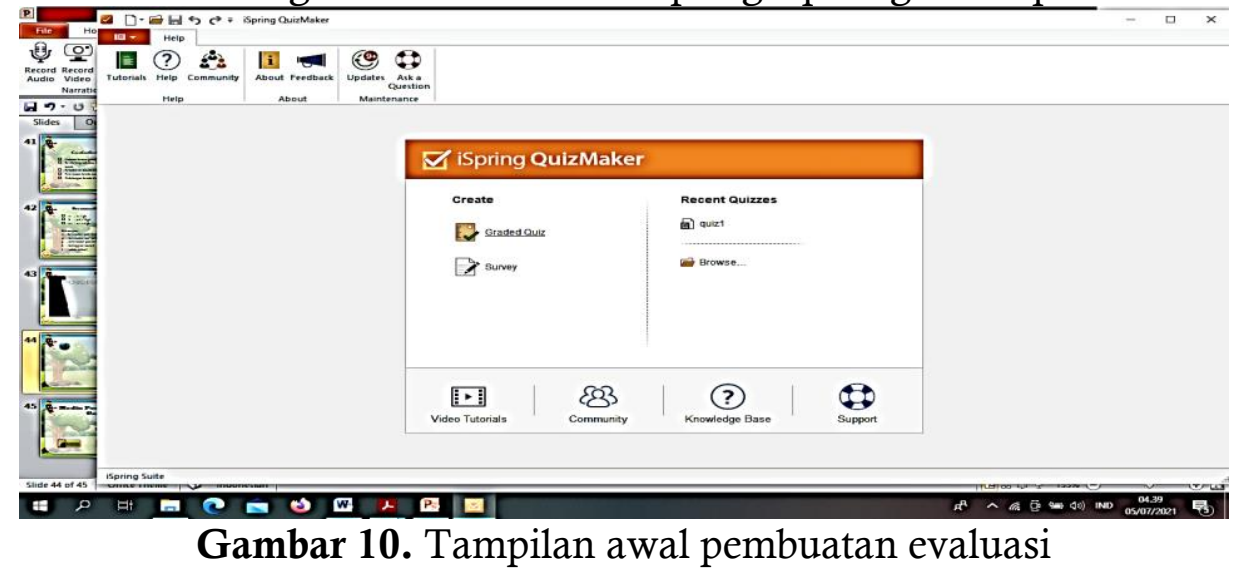

9. Memasukan soal evaluasi dengan cara klik menu question $>$ multiple choice.

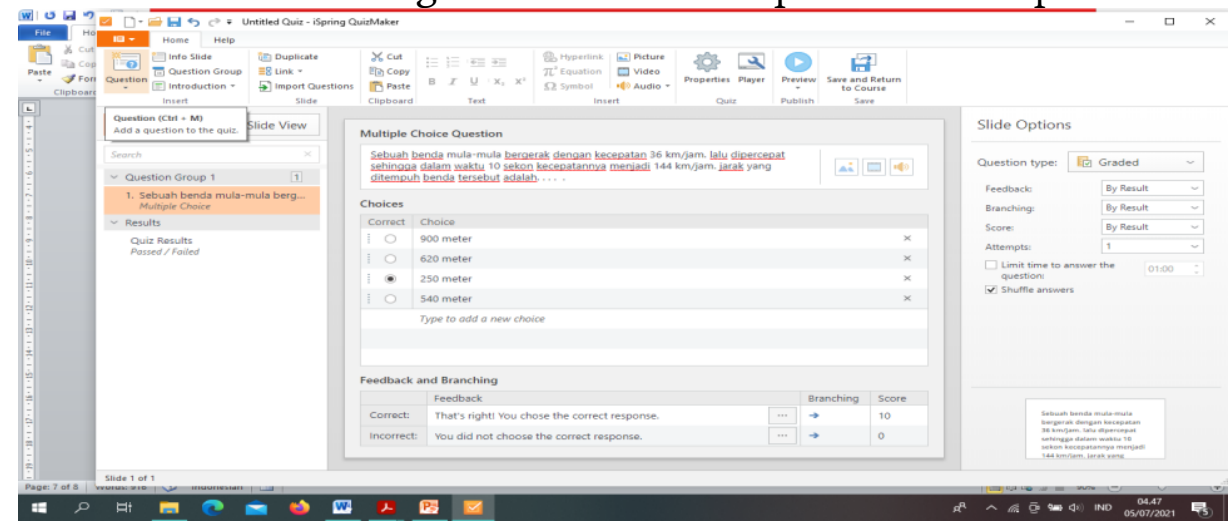

Gambar 11. Tampilan pembuatan soal evaluasi

10. Setelah selesai memasukan soal klik menu properties $>$ quis scoring untuk mengatur skor atau penilaian dan KKM. Setelah selesai klik save and return to course. 


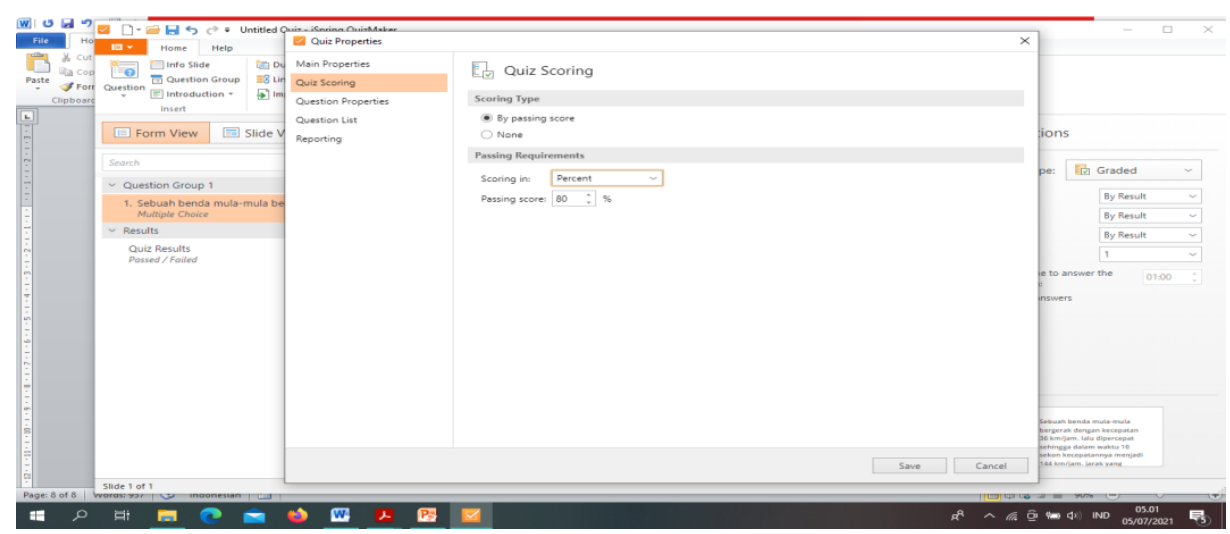

Gambar 12. Tampilan saat pengaturan skor dan KKM pada evaluasi

\section{Implementasi kode program}

Pada tahap implementasi kode program ini kegiatan yang dilakukan sebagai berikut.

1. Memasukan perintah pada setiap ikon yang telah dibuatkan dalam slide dengan cara klik pada ikon>insert>action>hyperlink. Hal ini bertujuan agar ketika ikon di klik maka tampilan akan berpindah sesuai kode perintah yang telah dimasukan.

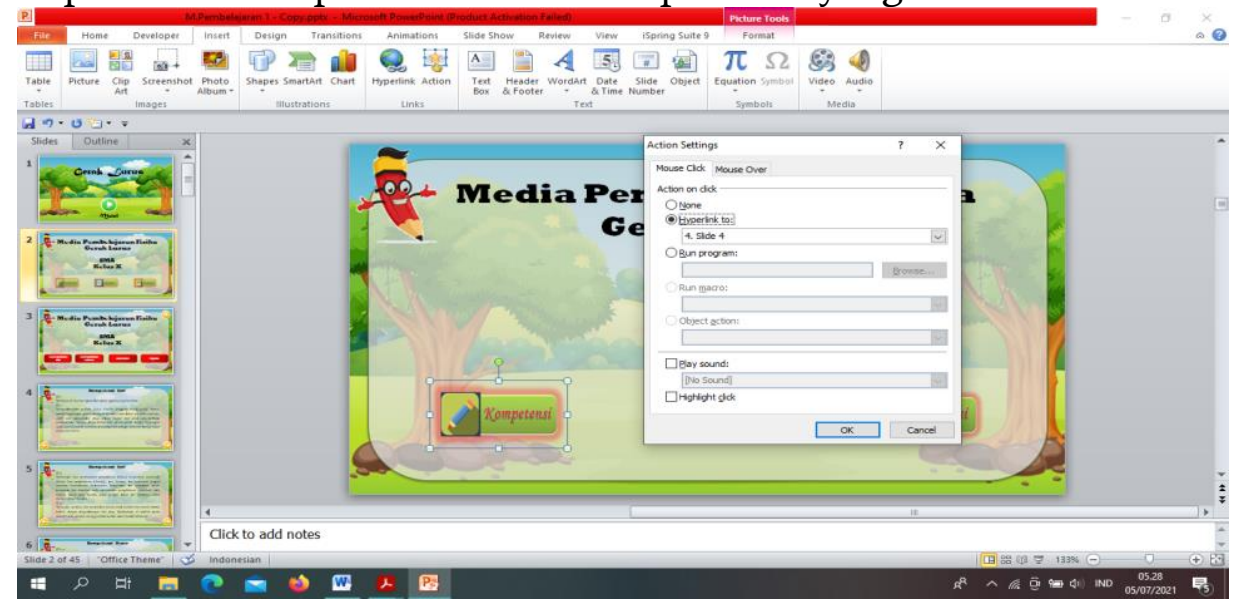

Gambar 13. Tampilan saat memasukan kode perintah pada ikon

2. Mengkonversi desain aplikasi dalam format microsoft power point ke dalam format HTML 5 menggunakan iSpring Suite 9 dengan cara klik menu iSpring>publish.

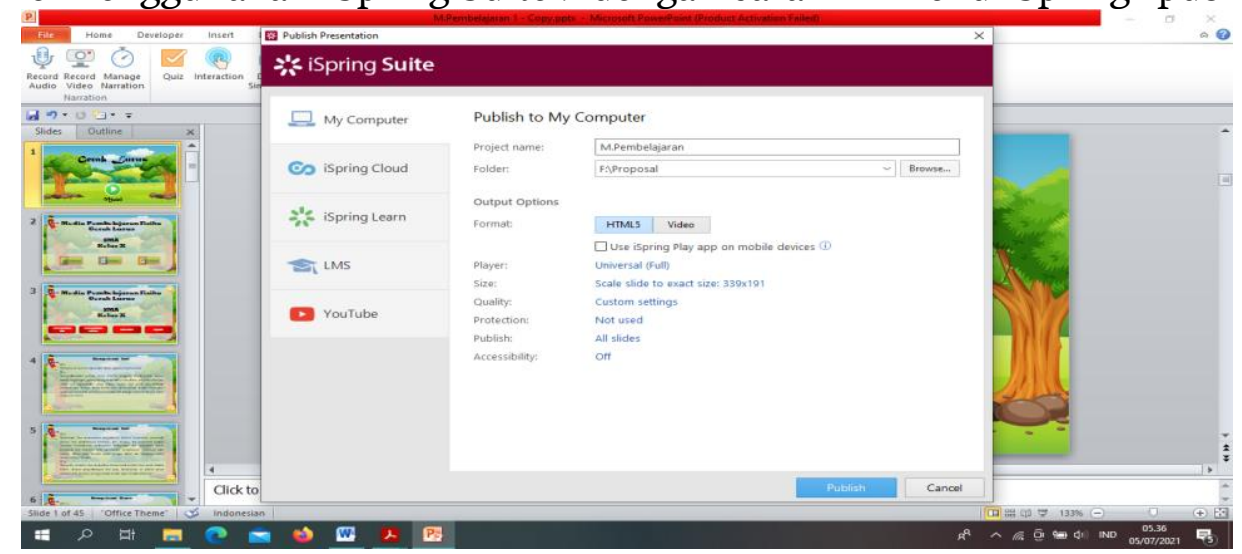

Gambar 14. Tampilan saat mengkonversi power point menjadi format HTML 5

3. Mengkonversi HTML 5 menjadi aplikasi android menggunakan web 2 APK Builder Pro dengan cara, buka aplikasi web 2 APK Builder Pro> Local HTML Website> masukan nama aplikasi pada kolom application tittle> pilih file yang telah dikonversi dalam format HTML 5 pada kolom directory of local website> klik generate apk. 


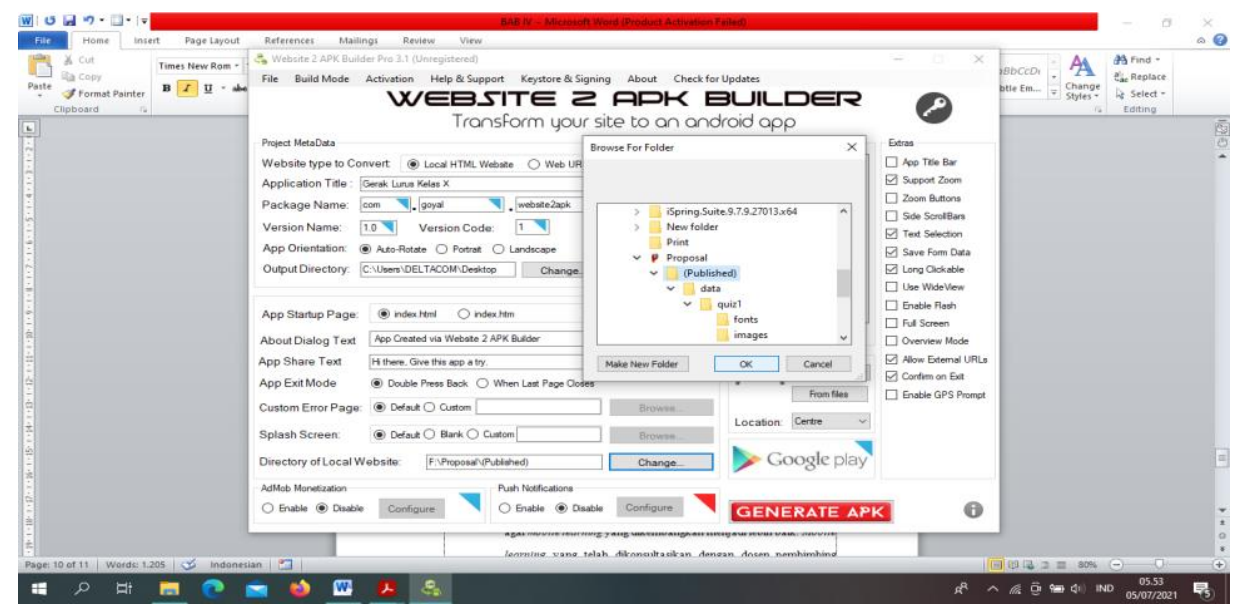

Gambar 15. Tampilan saat menkonversi HTML 5 menjadi aplikasi android

4. Memindahkan aplikasi dari leptop ke telepon genggam android lalu diinstal untuk uji coba kelancaran saat digunakan dan sebelum dilakukan validasi.

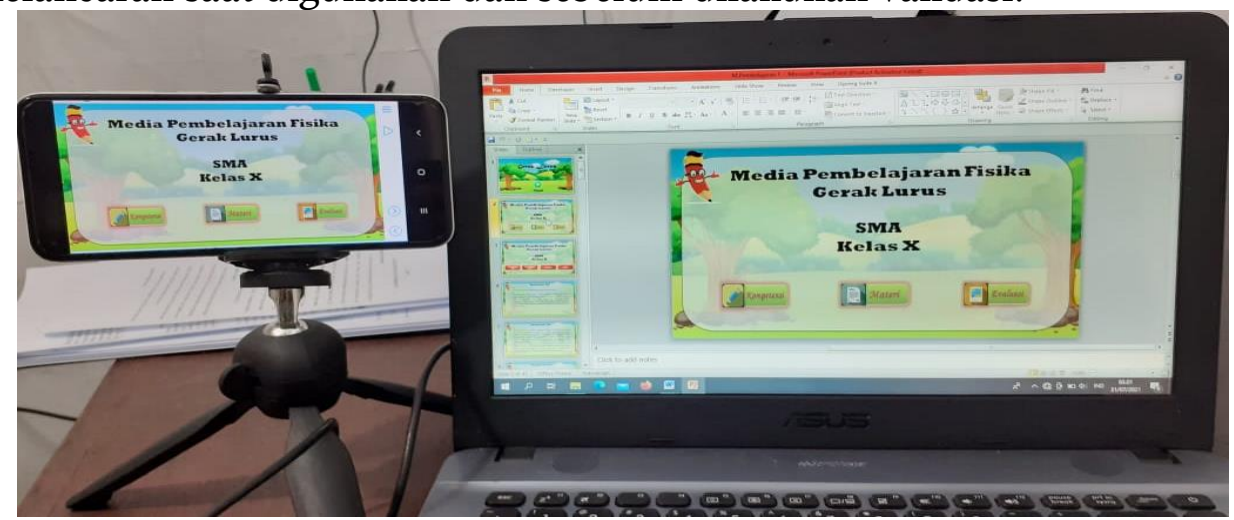

Gambar 16. Tampilan aplikasi pada telepon genggam.

\section{Pengujian aplikasi}

\section{Pengujian internal}

Tahap ini bertujuan agar mendapatkan saran dan masukan dari dosen pembimbing sehingga mobile learning yang dikembangkan menjadi lebih baik. Hasil pengujian internal disajikan pada Tabel 3.

Tabel 3. Kritik dan saran berdasarkan hasil validasi internal

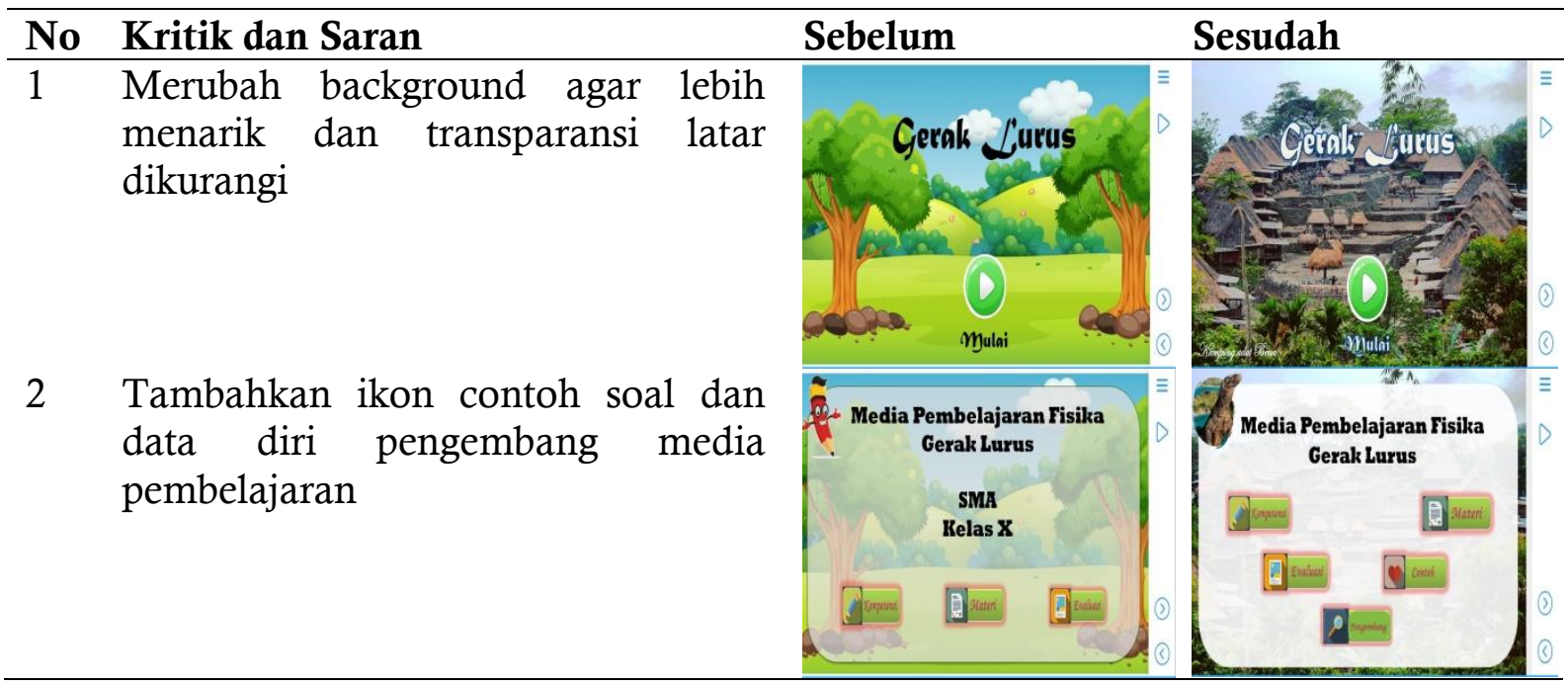




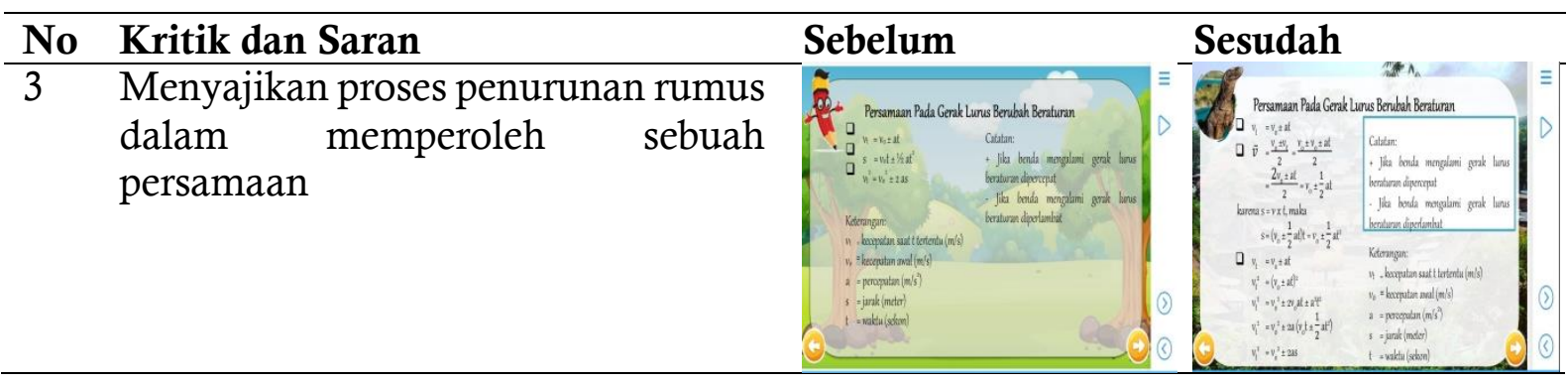

\section{Pengujian oleh validator}

Mobile learning yang telah dikembangkan dan direvisi sesuai kemudian diserahkan kepada validator untuk diberikan penilaian atau validasi berkaitan dengan aspek kevalidan.

Ahli Media

Validasi oleh ahli media mencakup 3 aspek penilaian dan dijabarkan dalam 14 pertanyaan/pernyataan. Validasi ini bertujuan untuk melihat kelayakan media yang dikembangkan. Hasil validasi oleh ahli media disajikan pada Tabel 4.

Tabel 4. Data hasil penilaian mobile learning ahli media

\begin{tabular}{llll}
\hline No & Aspek yang Dinilai & Persentase Skor (\%) & Kriteria \\
\hline 1 & Tampilan & 72 & Layak/Baik \\
2 & Perangkat Lunak & 88 & Sangat Layak/Sangat Baik \\
3 & Keterlaksanaan & 80 & Layak/Baik \\
\hline Rata-rata & $\mathbf{8 0}$ & Layak/Baik \\
\hline
\end{tabular}

Berdasarkan Tabel 4, skor penilaian tertinggi oleh ahli media pada mobile learning yang dikembangkan diperoleh pada aspek perangkat lunak sebesar $88 \%$ dan skor terendah pada aspek tampilan sebesar $72 \%$ sedangkan persentase rata-rata memperoleh skor seluruh aspek sebesar $80 \%$ dengan kriteria layak/baik. Rata-rata yang diperoleh kesimpulan bahwa menurut ahli media mobile learning yang telah dikembangkan termasuk dalam kriteria layak/baik. Beberapa saran untuk perbaikan produk yang dikembangkan disajikan pada Tabel 5.

Tabel 5. Kritik dan saran ahli media

\begin{tabular}{|l|l|l|l|}
\hline No & Kritik dan Saran & Sebelum & Sesudah \\
\hline 1 & $\begin{array}{l}\text { Tambahkan audio dan kalimatnya } \\
\text { jangan terlalu panjang }\end{array}$ & $\begin{array}{l}\text { Tambahkan ikon menu home pada } \\
\text { setiap tampilan }\end{array}$ &
\end{tabular}

\section{Ahli Materi}

Tabel 6 menujukkan hasil validasi oleh ahli materi yang mencakup 4 aspek penilaian dengan 15 pernyataan dan bertujuan untuk melihat kelayakan materi gerak lurus. 
Tabel 6. Data hasil penilaian mobile learning ahli materi

\begin{tabular}{llll}
\hline No & Aspek yang Dinilai & Persentase Skor (\%) & Kriteria \\
\hline 1 & Kurikulum & 75 & Layak/Baik \\
2 & Penyajian Materi & 75 & Layak/Baik \\
3 & Evaluasi & 60 & Cukup Layak/Cukup Baik \\
4 & Kebahasaan & 70 & Layak/Baik \\
\hline Rata-rata & $\mathbf{7 0}$ & Layak/Baik \\
\hline
\end{tabular}

Berdasarkan Tabel skor penilaian tertinggi oleh ahli materi pada mobile learning yang dikembangkan diperoleh pada aspek kurikulum dan penyajian materi sebesar $75 \%$ dan skor terendah pada aspek evaluasi sebesar 60\% sedangkan persentase rata-rata memperoleh skor seluruh aspek sebesar $70 \%$ dengan kriteria layak/baik. Rata-rata yang diperoleh kesimpulan bahwa menurut ahli materi mobile learning yang telah dikembangkan termasuk dalam kriteria layak/baik.

Tabel 7. Kritik dan saran ahli materi

\begin{tabular}{lllll}
\hline No & Kritik dan Saran & \multicolumn{1}{c}{ Sebelum } \\
\hline 1 & $\begin{array}{l}\text { Perbaiki indikator dan tujuan } \\
\text { pembelajaran }\end{array}$ & $\begin{array}{l}\text { Tambahkan pengantar gerak lurus } \\
\text { sebelum ke materi inti }\end{array}$ &
\end{tabular}

Tahap Implementation

Tahap implementasi ini bertujuan untuk melihat kesalahan-kesalahan kecil yang luput dari pengamatan ahli media dan ahli materi.

\section{Penilaian Guru Fisika}

Hasil penilaian guru fisika pada mobile learning yang telah dikembangkan tersaji dalam Tabel 8 berikut.

Tabel 8. Data hasil penilaian mobile learning guru fisika

\begin{tabular}{llll}
\hline No & Aspek yang Dinilai & Persentase Skor (\%) & Kriteria \\
\hline 1 & Kurikulum & 85 & Sangat Layak/Sangat Baik \\
2 & Penyajian Materi & 82,5 & Layak/Baik \\
3 & Evaluasi & 83,3 & Layak/Baik \\
4 & Kebahasaan & 80 & Layak/Baik \\
5 & Tampilan & 80 & Layak/Baik \\
6 & Perangkat Lunak & 82 & Layak/Baik \\
7 & Keterlaksanaan & 85 & Sangat Layak/Sangat Baik \\
\hline Rata-rata & $\mathbf{8 2 , 5 4}$ & Layak/Baik \\
\hline
\end{tabular}

Berdasarkan Tabel skor penilaian tertinggi oleh guru fisika pada mobile learning yang dikembangkan diperoleh pada aspek kurikulum dan keterlaksanaan sebesar $85 \%$ dan skor terendah pada aspek kebahasaan dan tampilan sebesar 80\% sedangkan persentase rata-rata perolehan skor seluruh aspek sebesar 82,54\%. Rata-rata yang diperoleh 
kemudian dikonversikan dan diperoleh kesimpulan bahwa menurut guru fisika mobile learning yang telah dikembangkan termasuk dalam kriteria layak/baik.

\section{Penilaian Peer Reviewer}

Hasil penilaian peer reviewer pada mobile learning yang telah dikembangkan tersaji dalam Tabel 9 berikut.

Tabel 9. Data hasil penilaian mobile learning peer reviewer

\begin{tabular}{llll}
\hline No & Aspek yang Dinilai & Persentase Skor (\%) & Kriteria \\
\hline 1 & Kurikulum & 82,5 & Layak/Baik \\
2 & Penyajian Materi & 82,5 & Layak/Baik \\
3 & Evaluasi & 86,66 & Sangat Layak/Sangat Baik \\
4 & Kebahasaan & 88,75 & Sangat Layak/Sangat Baik \\
5 & Tampilan & 89 & Sangat Layak/Sangat Baik \\
6 & Perangkat Lunak & 84 & Sangat Layak/Sangat Baik \\
7 & Keterlasanaan & 86,25 & Sangat Layak/Sangat Baik \\
\hline Rata-rata & $\mathbf{8 5 , 6 6}$ & Sangat Layak/Sangat Baik \\
\hline
\end{tabular}

Berdasarkan Tabel skor penilaian tertinggi oleh peer reviewer pada mobile learning yang dikembangkan diperoleh pada aspek tampilan sebesar 89\% dan skor terendah pada aspek kurikulum dan penyajian materi sebesar $82,5 \%$ sedangkan persentase rata-rata perolehan skor seluruh aspek sebesar 85,66\%. Rata-rata yang diperoleh kemudian dikonversikan dan diperoleh kesimpulan bahwa menurut peer reviewer mobile learning yang telah dikembangkan termasuk dalam kriteria sangat layak/sangat baik.

\section{Penilaian Siswa}

Hasil penilaian siswa pada mobile learning yang dikembangkan tersaji dalam Tabel 10 berikut.

Tabel 10. Data hasil penilaian mobile learning siswa

\begin{tabular}{llll}
\hline No & Aspek yang Dinilai & Persentase Skor (\%) & Kriteria \\
\hline 1 & Minat Terhadap Media & 94 & Sangat Layak/Sangat Baik \\
2 & Penguasaan & 91,33 & Sangat Layak/Sangat Baik \\
3 & Tampilan & 92 & Sangat Layak/Sangat Baik \\
4 & Keterlaksanaan & 96 & Sangat Layak/Sangat Baik \\
\hline Rata-rata & $\mathbf{9 3 , 3 3}$ & Sangat Layak/Sangat Baik \\
\hline
\end{tabular}

Berdasarkan Tabel semua aspek yang dinilai siswa memiliki kriteria sangat layak/sangat baik terutama pada aspek keterlaksanaan yang memperoleh persentase skor paling tinggi yaitu 96\%. Rata-rata yang diperoleh sebesar 93,33\% kriteria kelayakan mobile learning sangat layak/sangat baik untuk digunakan sebagai sumber belajar bagi siswa kelas X pada materi Gerak Lurus.

\section{Tahap Evaluation}

Tahap evaluasi peneliti melakukan revisi tahap akhir pada mobile learning sesusai masukan dari guru fisika, siswa, dan peer reviewer. Revisi akhir ini bertujuan agar mobile learning yang dikembangkan benar-benar sesuai dan layak serta befektif digunakan sebagai sumber belajar. 


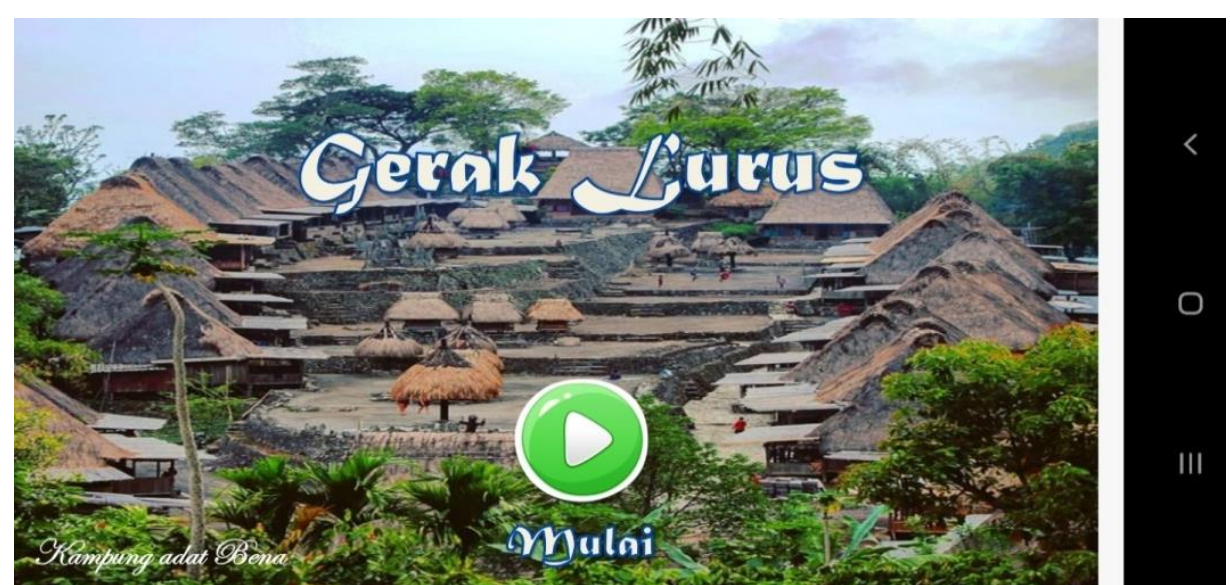

Gambar 17. Tampilan awal mobile learning

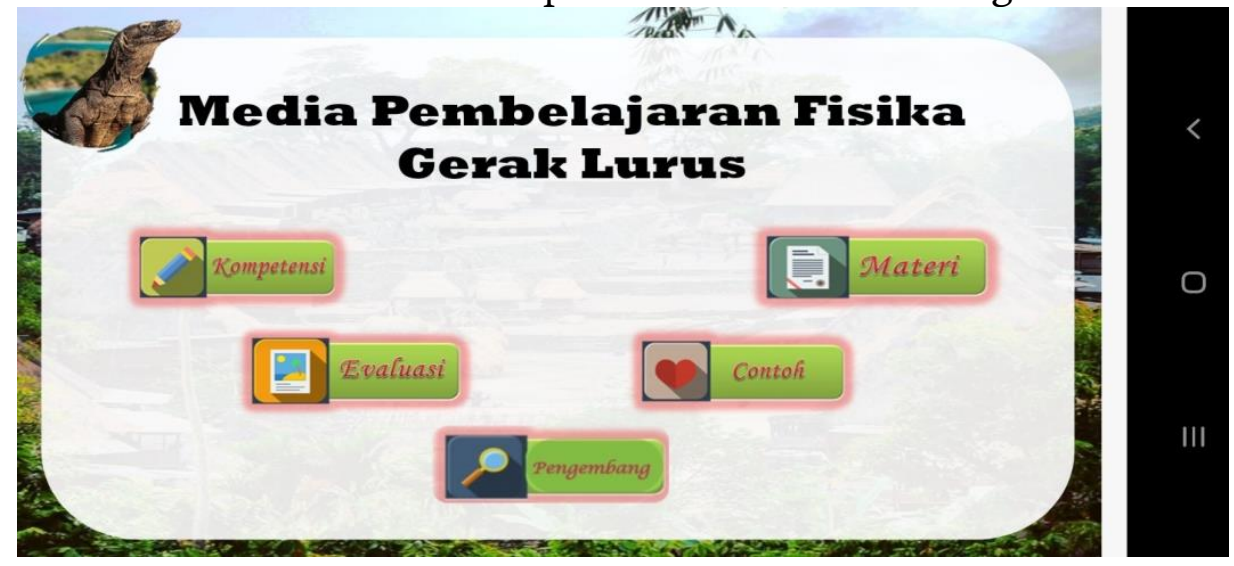

Gambar 18. Tampilan menu home mobile learning

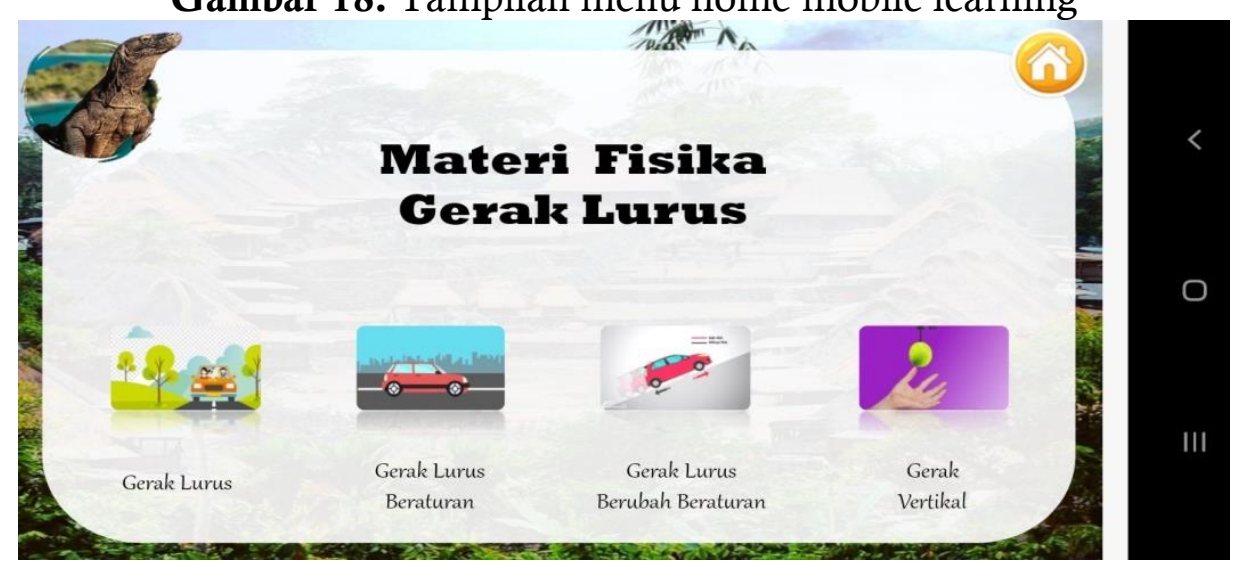

Gambar 19. Tampilan menu materi pembelajaran mobile learning

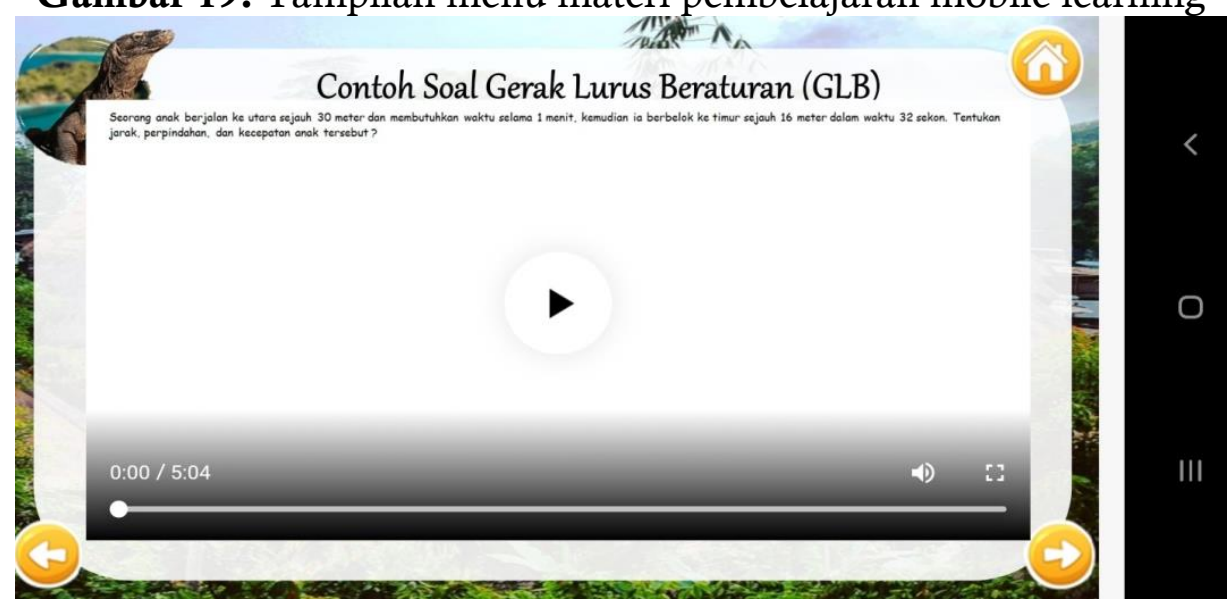

Gambar 20. Tampilan contoh soal

Lensa: Jurnal Kependidikan Fisika | December 2021, Volume 9, Number 2 
Pengembangan mobile learning dilakukan dengan mengacu pada storyboard yang telah dibuat pada tahap desain. Peneliti menuangkan hasil desain aplikasi dalam format microsoft power point yang sudah di konversi ke format HTML 5 dengan menggunakan Ispring Suite. Selanjutnya konversiHTML 5 ke aplikasi dengan meggunakan website 2 APK Builder Pro sehingga terbentuk sebuah produk aplikasi. Sebelum mobile learning yang sudah dikembangkan divalidasi oleh validator produk hasil penelitian dievaluasi kembali secara internal dengan tujuan agar mobile learning yang dikembangkan benarbenar siap untuk divalidasi. Mobile learning yang telah direvisi sesuai dengan masukan dan saran dari dosen pembimbing kemudian diserahkan kepada ahli media dan ahli materi untuk diberikan penilaian atau validasi berkaitan dengan aspek kevalidan.

Hasil validasi oleh ahli media terdapat beberapa saran dan masukan bagi peneliti agar memperbaiki mobile learning yang telah dikembangkan sehingga lebih baik dalam penggunaannya sebagai sumber belajar. Skor penilaian terendah pada aspek tampilan sebesar $72 \%$ hal ini dikarenakan penggunaan kalimat yang terlalu panjang dan juga animasi yang dibuat masih sangat standar serta beberapa halaman yang tidak disediakan menu home yang menyebabkan kesulitan saat kembali ke menu awal. Produk mobile learning yang telah dikembangkan mendapatkan hasil penilaian rata-rata sebesar $80 \%$ dengan kriteria layak/baik.

Hasil validasi oleh ahli materi terdapat beberapa saran dan masukan bagi peneliti agar memperbaiki mobile learning yang telah dikembangkan sehingga lebih baik dalam penggunaannya sebagai sumber belajar diantaranya memperbaiki indikator dan tujuan pembelajaran, menambahkan pengantar mengenai gerak lurus sebelum masuk ke materi inti serta memberikan variasi soal pada bagian evaluasi. Skor penilaian terendah pada aspek evaluasi sebesar $60 \%$ hal ini dikarenakan kurangnya variasi soal dan beberapa soal evaluasi yang dinilai kurang sesuai dengan materi dan tujuan pembelajaran serta tujuan pembelajaran dan indikator yang belum lengkap. Produk mobile learning yang telah dikembangkan mendapatkan hasil penilaian rata-rata sebesar $70 \%$ dengan kriteria layak/baik.

Hasil uji coba terbatas memperoleh penilaian rata-rata dari 2 guru fisika sebesar $82,54 \%$ dengan kriteri layak/baik, penilaian rata-rata dari 4 orang peer reviewer sebesar $85,66 \%$ dengan kriteria sangat layak/sangat baik sedangkan penilaian rata-rata 10 siswa SMAN 1 Ende sebesar 93,33\% dengan kriteria sangat layak/sangat baik. Hasil uji coba terbatas memperoleh hasil lebih baik dibandingkan dengan penelitian dan pengembangan yang dilakukan Ertikanto (2017) yang memperoleh hasil penilaian guru fisika sebesar $81,25 \%$; penilaian peer reviewer sebesar $82 \%$; serta penilaian rata-rata siswa sebesar $83 \%$. Perbedaan perolehan skor pada uji coba terbatas sangat signifikan dibandingkan dengan skor yang diberikan oleh ahli media dan ahli materi. Hal ini dikarenakan sebelum dilakukan uji coba terbatas peneliti terlebih dahulu memperbaiki aplikasi sesuai saran dan masukan dari ahli media dan ahli materi.

Berdasarkan hasil uji coba terbatas hasil penilaian yang diperoleh lebih unggul dibandingkan dengan penelitian dan pengembangan yang dilakukan Wahyono, Kadek, dan Gagese (2018) yang mengungkapkan bahwa produk hasil pengembangan mobile learning dinyatakan layak digunakan sebagai sumber belajar berdasarkan berdasarkan penilaian ahli, guru fisika, dan peer reviewer dengan kategori baik sedangkan hasil uji coba terbatas penelitian ini memperoleh kriteria sangat layak. Selain itu produk mobile learning yang dikembangkan memiliki beberapa keunggulan diantaranya: ukuran file yang relatif kecil yakni $93 \mathrm{mb}$, bisa diakses dimana saja dan kapan saja serta tidak membutuhkan kuota dan konektivitas internet untuk mengakses serta sangat efektif digunakan sebagai sumber belajar. 


\section{KESIMPULAN}

Penelitian dan pengembangan yang peneliti lakukan telah menghasilkan sebuah produk berupa mobile learning sebagai sumber belajar pada materi Gerak Lurus untuk Siswa kelas X SMA. Berdasarkan hasil penelitian dan pembahasan dapat disimpulkan mobile learning yang dikembangkan layak/baik dan efektif digunakan sebagai sumber belajar pada materi Gerak Lurus untuk siswa kelas X berdasarkan penilaian ahli media sebesar $80 \%$, penilaian ahli materi sebesar $70 \%$, dan penilaian guru fisika sebesar $82,54 \%$.

Hasil uji coba terbatas menunjukan mobile learning yang dikembangkan sangat layak/sangat baik dan sangat efektif digunakan sebagai sumber belajar dengan rata-rata penilaian oleh peer reviewer sebesar $85,66 \%$ dan rata-rata penilaian oleh siswa sebesar $93,33 \%$.

\section{SARAN}

Mobile learning yang dikembangkan masih perlu dimaksimalkan lagi dan mungkin bisa menjadi perbaikan bagi peneliti selanjutnya yakni: menambahkan atau mengganti materi pelajaran dan juga menambahkan fitur-fitur, animasi, maupun tampilan yang lebih menarik.

\section{UCAPAN TERIMA KASIH}

Ucapan terima kasih ditujukan kepada semua pihak yang turut membantu baik secara langsung maupun tidak langsung sehingga penelitian dan pengembangan mobile learning ini dapat diselesaikan.

\section{DAFTAR PUSTAKA}

Amry, A. B. (2014). The impact of WhatApp mobile social learning on the achievement and attitudes of female students compared with face to face learning in the classroom. European Scientific Journal. 10(22):116-136. http://eujournal.org/index.php/esj/article/view/3909

Ardiansyah, A. A., \& Nana. (2020). Peran Mobile Learning Sebagai Inovasi Dalam Pembelajaran Di Sekolah. Indonesian Journal of Education Research and Review. 22 (1): 65-70. Diakses dari https://doi.org/10.24832/jpnk.v18i2.

Astra, I Made, Umiatin dan Dian Ruharman. (2012). Aplikasi Mobile Learning Fisika dengan Menggunakan Adobe Flash sebagai Media Pembelajaran Pendukung. Jurnal Pendidikan Dan Kebudayaan. 18 (II). 174-180.

Astuti, I. A. D., Sumarni, R. A., \& Saraswati, D. L. (2017). Pengembangan Media Pembelajaran Fisika Mobile Learning berbasis Android. Jurnal Penelitian \& Pengembangan Pendidikan Fisika. 3(2): 165-169.

Attewell, J. (2005). Mobile learning: reaching hard-to-reach learners and bridging thedigital divide. Methods and Technologies for Learning.

Baskara, A., Atika, L., \& Oktaviani, N. (2020). Sistem Monitoring Data Aset Dan Inventaris Di Universitas Bina Darma Berbasis Web. Physics Education Journal. 4(2): 91-102).

Cahyadi, A. (2019). Pengembangan Media dan Sumber Belajar: Teori dan Prosedur. Laksita Indonesia.

Calimag, V., Miguel, A. G., Nealbert, J., Conde, R. S., \& Aquino, L. B. (2014). Ubiquitous Learning Environment Using Android Mobile Application. International Journal of Research in Engineering \& Technology. 2(2):119-128.

CNN Indonesia. Pengguna Internet Kala WFH Corona Meningkat 40 Persen di RI. (https://www.cnnindonesia.com/teknologi/20200408124947-213-3541-491594/ pengguna-internet-kala-wfh-corona-meningkat-40-persen-di-ri). Diakses pada tanggal 9 Februari 2021. 
Gagese, N., Wahyono, U., \& Kendek, Y. (2018). Pengembangan Mobile Learning Berbasis Android pada Materi Listrik Dinamis. Jurnal Pendidikan Fisika Tadulako Online (JPFT). 6(1): 121-131. Diperoleh melalui situs internet https://doi.org/10.22487/j25805924.2018.

Hafid, H. A. (2011). Sumber dan Media Pembelajaran. Jurnal Sulesana. 4(2): 25-35.

Kemendikbud. (2020). Surat Edaran Mendikbud No 4 Tahun 2020 Tentang Pelaksanaan Kebijakan Pendidikan Dalam Masa Darurat Penyebaran Corona Virus Disease (Covid- 1 9) - Pusdiklat Pegawai Kementerian Pendidikan dan Kebudayaan. https://Pusdiklat.Kemdikbud.Go.Id/.

Ma'rifa, H.Kamaludin, \& H. Fihrin. (2018). Analisis Pemahaman Konsep Gerak Lurus pada Siswa SMA Negeri di Kota Palu. Jurnal Pendidikan Fisika Tadulako (JPFT). 11(1): $1-15$

Mulyono, \& Ampo, I. (2021). Pemanfaatan Media Dan Sumber Belajar Abad 21. Paedagogia: Jurnal Pendidikan. 4(2): 25-34. Diperoleh melalui situs internet https://doi.org/10.24239/pdg.vol9.iss2.72

Oye, N. D., Salleh, M., \& A., N. (2012). E-Learning Methodologies and Tools. International Journal of Advanced Computer Science and Applications. 3(2): 48-52.

Pribadi, B. A. (2014). Desain dan Pengembangan Program Pelatihan Berbasis Kompetensi Implementasi Model ADDIE. In Prenada Media Group.

Purnama, R., Sesunan, F., \& Ertikanto, C. (2017). Pengembangan Media Pembelajaran Mobile Learning Berbasis Android Sebagai Suplemen Pembelajaran Fisika SMA Pada Materi Usaha Dan Energi. Jurnal Pembelajaran Fisika Universitas Lampung. 1(2): 91-102.

Rahayu, M. S. I. (2017). Pengembangan Media Pembelajaran Berbasis Mobile Learning Pada Platform Android Sebagai Sumber Belajar Untuk Meningkatkan Kemandirian Belajar Dan Hasil Belajar Fisika Perserta Didik Kelas X. Skripsi. https://eprints.uny.ac.id/48681/. Diakses pada tanggal 15 Februari 2020.

Ramadan, F. A., \& Arfinanti, N. (2019). Pengembangan Mobile Learning Rensi (Relasi dan Fungsi) Berbasis Android pada Pokok Bahasan Relasi dan Fungsi sebagai Sumber Belajar Mandiri Siswa Kelas VIII SMP. Jurnal Pengembangan Pembelajaran Matematika. 16(7): 1-6. Diperoleh melalui situs internet https://doi.org/10.14421/jppm.2019.011-05

Sefriani, R., \& Sepriana, R. (2020). Pengembangan Media E-Learning Berbasis Schoology pada Pembelajaran Kurikulum Pendidikan Teknologi dan Kejuruan. Edukatif: Jurnal Ilmu Pendidikan. 14(4): 28-33.

Sugiyono. (2018). Metode Penelitian Kuantitatif, Kualitatif, dan R\&D. Bandung: Alfabeta. Prof. Dr. Sugiyono. 2018. Metode Penelitian Kuantitatif, Kualitatif, Dan R\&D. Bandung: Alfabeta.

Suhirman, S. (2018). Pengelolaan Sumber Belajar Dalam Meningkatkan Pemahaman Peserta Didik. Al Fitrah: Journal Of Early Childhood Islamic Education. 9(2): 8490.

Syaputrizal, N., \& Jannah, R. (2019). Media Pembelajaran Fisika Berbasis Mobile Learning pada Platform Android Menggunakan Aplikasi App Inventor untuk Meningkatkan Kemandirian Belajar Peserta Didik. Natural Science Journal. 176: 129-138.

Tim Pengembang Ilmu Pendidikan FIP-UPI. (2007). Ilmu dan Aplikasi Pendidikan. Jakarta: PT. Imperial Bhakti Utama. Bagian 4, Hlm 503.

Yuniati, L. (2012). Pengembangan Media Pembelajaran Mobile Learning Efek Doppler sebagai Alat Bantu Dalam Pembelajaran Fisika yang Menyenangkan. Jurnal 
Penelitian

Pembelajaran

Fisika.

8(1):

$53-60$. https://doi.org/10.26877/jp2f.v2i2/september.130 